UDC 303.725.36:159.9.015:159.964.21:519.86 (045),

DOI: $10.18372 / 1990-5548.52 .11885$

A. V. Goncharenko

\title{
A CONCEPT OF MULTI-OPTIONAL OPTIMALITY AT MODELING IDEAL GAS ISOTHERMAL PROCESSES
}

\author{
Educational \& Research Aerospace Institute, National Aviation University, Kyiv, Ukraine \\ E-mail: andygoncharenco@yahoo.com
}

\begin{abstract}
Considered a multi-optional method of finding a relation between an ideal gas parameters for an isothermal reversible equilibrium process. Specific volume hybrid optional functions are taken into account at the optimization of an objective functional which includes a type of entropy uncertainty measure for those specific volume hybrid optional functions. Required mathematical models for obtaining the optimal multi-optional distributions are introduced. Calculation experiments are carried out. The necessary diagrams are plotted.
\end{abstract}

Index Terms-Isothermal process; reversible equilibrium process; process parameters relation; optimization; entropy extremization principle; multi-optionality; hybrid optional functions; optimal distribution; variational problem.

\section{INTRODUCTION}

Modeling of systems and processes in scientific point of view sometimes requires creation of elaborated mathematical models. Development of scientific principles based upon substantiated concepts makes it possible to discover new theoretical explanations even to already well-known dependences.

The spectrum of such new theoretical background applications or at least attempts to look at considered scientific problems is enormously wide. For example, one can deal with aircraft noise [1], which needs to be reduced however absolute silence is not achievable. Therefore the one faces the problem of the aircraft noise optimal reduction.

Other directions of research touch aspects of aeronautical engineering maintenance technologies [2], estimation of quality parameters in the radio flight support operational systems [3].

Sometimes such problems may result in acceptable level of a criterion, likewise applicably to design works [4] or control functioning modes [5].

In all mentioned above there is a temptation to use an entropy approach proposed and developed in a series of monographs by professor Kasianov V. A. and his follower (National Aviation University, Kyiv, Ukraine) [6] - [9].

Thus, the purpose of the paper is to give a new impulse to the multi-optional hybrid functions entropy application with respect to the unsolved part of the general problem of the optimum finding concerning an equilibrium reversible isothermal process of an ideal gas [10], [11].

A combined multi-optional approach adopts similar ones initiated in papers [12] - [19].

\section{SOLUTION OF THE PROBLEM}

\section{A. Traditional Theory Approach}

For a reversible isothermal process of an ideal gas [10, pp. 377-414], [11, pp. 53, 54, (3.18-3.21)]

$$
q_{\mathrm{I}-\mathrm{II}}=R T \ln \left(\frac{v_{\mathrm{II}}}{v_{\mathrm{I}}}\right)
$$

where $q_{\mathrm{I}-\mathrm{II}}$ is the net amount of heat flowing into a thermodynamic system during the reversible isothermal process "I-II", the subscripts I and II refer to different physical states "I" and "II" of the same sample of the ideal gas with the temperature held constant; $R$ is the specific gas constant; $T$ is the process temperature; $v_{\text {II }}$ and $v_{\mathrm{I}}$ stand for the specific volumes of the gas at the final "II" and initial "I" states of the process correspondingly.

Equation (1) is obtained by integrating the equation of the first law of thermodynamics in differential form with taking into account the conditions of isothermal process: $T=$ const, i.e. $d T=0$, and ideal gas law.

\section{B. Multi-Optional Concept}

On the other hand one can present the amount of heat $q_{\text {I-II }}$, although defined with (1), as the difference between amounts of heat transmitted in two processes " $0-\mathrm{II}$ " and " $0-\mathrm{I}$ ". The process from the state of " 0 " up to the state of "I" is the preliminary part with regards to the process from the state of "I " up to the state of "II". That is, the point which symbolizes the state of "I" belongs to both the previous fragmental process " $0-\mathrm{I} "$ and following it process "I-II". This means the continuity of the process of " $0-$ II" with the 
presence of the intermediate state point of "I". Thus we have the process of " $0-$ I - II".

The mentioned above speculations can be illustrated with a " $p-v$ ", where $p$ is a state parameter - pressure, diagram shown in Fig. 1.

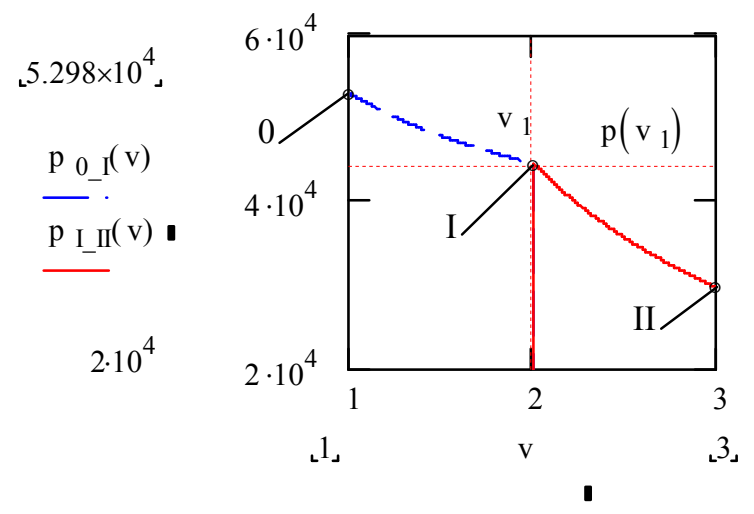

Fig. 1. Gas expansion in a process of " $0-$ II" between states of " 0 " and "II" with the intermediate state point of "I"

In Figure $1 \mathrm{v}$ stands for a corresponding specific volume and $\mathrm{p}_{0_{-} \mathrm{I}}(\mathrm{v}), \mathrm{p}_{\mathrm{I}_{\mathrm{II}} \mathrm{I}}(\mathrm{v})$ are related pressures changing in the corresponding processes of "0 - I", "I - II".

Let us consider

$$
q_{\mathrm{I}-\mathrm{II}}=q_{0-\mathrm{II}}-q_{0-\mathrm{I}} .
$$

Furthermore, also, at the presented problem setting, all the three processes of " $0-I$ ", "I-II", and " $0-\mathrm{I}-\mathrm{II}$ " are reckoned to be isothermal. In other words the process of " $0-$ II" is identical to the process of " $0-\mathrm{I}-\mathrm{II}$ ". Now we consider the isothermal process of " $0-$ II" with the intermediate state point of "I" belonging to the process of " 0 - II", being able to take any place on the curve of the isothermal process from the state of "I" up to the state of "II".

This case is illustrated with a " $p-v$ " diagram shown in Fig. 2.

The states of "I" and "II" of the isothermal process will be the options of the process, with the initial state of " 0 " of the process being not optional (see Fig. 2). The amounts of heat, $q_{0-\mathrm{I}}$ and $q_{0-\mathrm{II}}$, in such a case, will be considered as the options effectiveness functions: $q_{i}$. The corresponding specific volumes at the ends of the fragment processes of " $0-\mathrm{I}$ " and " $0-$ II" will be related with the specific volume hybrid optional functions: $v_{i}\left(q_{i}\right)$. An objective functional, which includes a type of entropy uncertainty measure for $v_{i}\left(q_{i}\right)$ is

$$
\begin{aligned}
\Phi_{v}=-\sum_{i=1}^{2} v_{i}\left(q_{i}\right) \ln v_{i}\left(q_{i}\right)+\frac{1}{R T} \sum_{i=1}^{2} v_{i}\left(q_{i}\right) & q_{i} \\
& +\sum_{i=1}^{2} v_{i}\left(q_{i}\right)
\end{aligned}
$$

where $v_{1}(\cdot)=\frac{v_{\mathrm{I}}}{v_{u}}$ and $v_{2}(\cdot)=\frac{v_{\mathrm{II}}}{v_{u}}, v_{u}$ is a unit specific volume; $q_{1}=q_{0-\mathrm{I}}$ and $q_{2}=q_{0-\mathrm{II}}$.

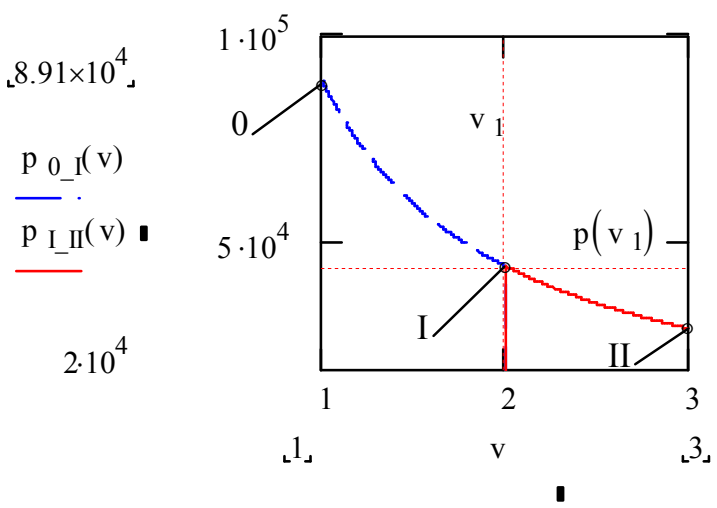

Fig. 2. Gas expansion in an isothermal process of " $0-$ I - II" between states of " 0 " and "II" with the intermediate state point of "I"

Thus, the specific volume hybrid optional functions $v_{1}($.$) and v_{2}(\cdot)$ do not necessarily have the same numerical values as related $v_{\mathrm{I}}$ and $v_{\mathrm{II}}$.

The necessary conditions of equation (3) extremum existence:

$$
\frac{\partial \Phi_{v}}{\partial v_{i}(\cdot)}=0
$$

yield

$$
\frac{\partial \Phi_{v}}{\partial v_{i}(\cdot)}=-\ln v_{i}(\cdot)+\frac{1}{R T} q_{i}=0, \quad \forall i \in \overline{1,2} .
$$

Then

$$
\begin{gathered}
\ln v_{1}(\cdot)-\frac{1}{R T} q_{1}=\ln v_{2}(\cdot)-\frac{1}{R T} q_{2} . \\
\frac{1}{R T}\left(q_{2}-q_{1}\right)=\ln v_{2}(\cdot)-\ln v_{1}(\cdot) . \\
q_{2}-q_{1}=R T \ln \left(\frac{v_{2}(\cdot)}{v_{1}(\cdot)}\right) .
\end{gathered}
$$

In actual fact (1) is obtained in the view of (8) with respect to the definitions of the specific volume hybrid optional functions given in the explanations to the objective functional (3). 
Concerning the optimization with respect to optimal specific volume hybrid optional functions $v_{1}(\cdot)$ and $v_{2}(\cdot)$ one can proceed from equation (5):

$$
\begin{gathered}
\ln v_{i}(.)=\frac{1}{R T} q_{i} . \\
v_{i}\left(q_{i}\right)=e^{\frac{1}{R T} q_{i}} .
\end{gathered}
$$

The ratio of the optimal specific volume hybrid optional functions $v_{1}(\cdot)$ and $v_{2}(\cdot)$ obtained from equation (10) yields relations (1) or (8).

From Eq. (10), (9) or (5) for option one

$$
q_{1}=q_{0-\mathrm{I}}=R T \ln \left(v_{1}\right) .
$$

On the other hand from Eq. (1)

$$
q_{1}=q_{0-\mathrm{I}}=R T \ln \left(\frac{v_{\mathrm{I}}}{v_{0}}\right) .
$$

Comparing equations (11) and (12), using the definitions of the specific volume hybrid optional functions given in the explanations to the objective functional (3)

$$
v_{1}=\frac{v_{\mathrm{I}}}{v_{u}}=\frac{v_{\mathrm{I}}}{v_{0}} .
$$

And for the presented problem setting expressed with equations (2) - (13)

$$
v_{u}=v_{0} .
$$

The same result as equation (13) is obtained for option two either in an analogous way, equations (11), (12), for $v_{2}$ or from $v_{2}$ with just a simple substitution of equation (14) into $v_{2}$ definition.

\section{CONCLUSIONS}

Proposed approach engaging an uncertainty measure in type of entropy, applied for specific volume hybrid optional functions optimization, allows finding an ideal gas reversible isothermal process relation in a new multi-optional way.

It broadens the horizons of scientific explanations for occurring processes optimality and encourages further research in the field of optional functions optimal distributions.

\section{REFERENCES}

[1] O. Zaporozhets, V. Tokarev, and K. Attenborough, Aircraft Noise. Assessment, prediction and control, Glyph International, Tailor and Francis, 2011, 480 p.

[2] S. Dmitriyev, A. Koudrin, A. Labunets, and M. Kindrachuk, "Functional Coatings Application for
Strengthening and Restoration of Aviation Products." Aviation. 2005. vol. 9, no. 4. pp. 39-45.

[3] O. Solomentsev, M. Zaliskyi, and O. Zuiev, "Estimation of Quality Parameters in the Radio Flight Support Operational System.” Aviation. 2016. vol. 20, no. 3. pp. 123-128.

[4] V. M. Sineglazov, A. A. Ziganshin, M. P. Vasylenko, "Computer-Aided Design of Wind Power System with Combined Rotor." Electronics and Control Systems. 2016. vol. 3(49). pp. 73-78. (ISSN: 19905548)

[5] O. A. Sushchenko, "Features of Control of Tracking Modes." Electronics and Control Systems. 2016. vol. 3(49). pp. 40-47. (ISSN: 1990-5548)

[6] V. Kasianov, Subjective Entropy of Preferences, Subjective Analysis: Monograph, Warsaw, Poland: Institute of aviation Publ., 2013, 644 p.

[7] V. A. Kasianov, Subjective Analysis: Monograph, Kyiv, Ukraine: National Aviation University, 2007, 512 p. (in Russian)

[8] V. A. Kasianov and A. V. Goncharenko, Variational Principles of Subjective Analysis. Modified EulerLagrange Variational Principle. Entropy Approach: Monograph, Kyiv, Ukraine: Publishing House "Pryoritety", 2015, 112 p. (in Russian)

[9] V. A. Kasianov and A. V. Goncharenko, Light and Shadow. Proportions of Shadow Economy. Entropy Approach: Monograph, Kyiv, Ukraine: Publishing House "Kafedra", 2013, 86 p. (in Russian)

[10] E. R. Jones and R. L. Childers, Contemporary college physics: $3^{\text {rd }}$ ed., USA: WCB/McGraw-Hill, $1999,1025 \mathrm{p}$.

[11] V. A. Kirillin, V. V. Sychov, and A. E. Sheindlin, Engineering Thermodynamics, Moscow, Russia: "Energoatomizdat", 1983, 414 p. (in Russian)

[12] V. Kasyanov and K. Szafran, "Some Hybrid Models of Subjective Analysis in the Theory of Active Systems." Transaction of the Institute of Aviation. 2015. vol. 240, no. 3. pp. 27-31. (ISSN 0509-6669)

[13] A. V. Goncharenko, "Some Identities of Subjective Analysis Derived on the Basis of the Subjective Entropy Extremization Principle by Professor V. A. Kasianov." Automatic Control and Information Sciences. 2014. vol. 2, no. 1. pp. 20-25. DOI: 10.12691/acis-2-1-4.

[14] A. V. Goncharenko, "Optimal Managerial and Control Values for Active Operation." Electronics and Control Systems. 2016. vol. 3(49). pp. 112-115. (ISSN: 1990-5548)

http://er.nau.edu.ua:8080/handle/NAU/22359

[15] A. V. Goncharenko, "Alternativeness of Control and Power Equipment Repair Versus Purchasing According to the Preferences of the Options." Electronics and Control Systems. 2016. vol. 4(50). pp. 98-101. (ISSN: 1990-5548) 
[16] A. V. Goncharenko, "One Theoretical Aspect of Entropy Paradigm Application to the Problems of Tribology." Problems of friction and wear. 2017. vol. 1(74). pp. 78-83. (ISSN: 0370-2197)

[17] A. V. Goncharenko, "An Alternative Method of the Main Psychophysics Law Derivation." Clin. and Exp. Psychol. 2017. vol. 3(155). pp. 1-5. (ISSN: 24712701) doi: 10.4172/2471-2701.1000155.

[18] A. V. Goncharenko, "Several Models of Physical Exercise Subjective Preferences." Clin. and Exp.
Psychol. 2016. vol. 2(121). pp. 1-6. (ISSN: 24712701) doi:10.4172/2471-2701.1000121.

[19] A. V. Goncharenko, “Aeronautical Engineering Maintenance Periodicity Optimization with the Help of Subjective Preferences Distributions." Proceedings of the NAU. 2017. vol. 2(71). pp. 51-56. (ISSN: 1813-1166 print / ISSN: 2306-1472 online) DOI: $10.18372 / 2306-1472.71 .11746$.

Received January 25, 2017.

Andriy Goncharenko. Doctor of Engineering. Associate Professor.

Aircraft Airworthiness Department, Educational \& Research Aerospace Institute, National Aviation University, Kyiv, Ukraine.

Education: Odessa Institute of Marine Engineers, Odesa, Ukraine (1984).

Research area: Operation and control in active systems, Flight safety, Variational principles.

Publications: more than a hundred.

E-mail: andygoncharenco@yahoo.com

А. В. Гончаренко. Концепція оптимальності багатоопійності при моделюванні ізотермічних процесів ідеального газу

Розглянуто багатоопційний метод знаходження відношення між параметрами ідеального газу для такого, що може бути проведений у зворотному напрямку рівноважного ізотермічного процесу. Гібридні опційні функції питомого об'єму взято до уваги при оптимізації цільового функціоналу, котрий включає міри невизначеності типу ентропії для тих гібридних опційних функцій питомого об’єму. Введено потрібні математичні моделі для отримання оптимальних багатоопційних розподілів. Виконано розрахункові експерименти. Побудовано необхідні діаграми.

Ключові слова: ізотермічний процес; такий, що може бути проведений у зворотному напрямку рівноважний процес; відношення між параметрами процесу; оптимізація; принцип екстремізації ентропії; багатоопційність; гібридні опційні функції; оптимальний розподіл; варіаційна задача.

Андрій Вікторович Гончаренко. Доктор технічних наук. Доцент.

Кафедра збереження льотної придатності авіаційної техніки, Навчально-науковий Аерокосмічний інститут, Національний авіаційний університет, Київ, Україна.

Освіта: Одеський інститут інженерів морського флоту, Одеса, Україна (1984).

Напрям наукової діяльності: експлуатація та керування в активних системах, безпека польотів, варіаційні принципи.

Кількість публікацій: понад сто.

E-mail: andygoncharenco@yahoo.com

А. В. Гончаренко. Концепция оптимальности многооционности при моделировании изотермических процессов идеального газа

Рассмотрен многоопционый метод нахождения отношения между параметрами идеального газа для обратимого равновесного изотермического процесса. Гибридные опционные функции удельного объема приняты ко вниманию при оптимизации целевого функционала, который включает меры неопределенности типа энтропии для этих гибридных опционных функций удельного объема. Введены требуемые математические модели для получения оптимальных многоопционных распределений. Выполнены расчетные эксперименты. Построены необходимые диаграммы.

Ключевые слова: изотермический процесс; обратимый равновесный процесс; отношение между параметрами процесса; оптимизация; принцип экстремизации энтропии; многоопционность; гибридные опционные функции; оптимальное распределение; вариационная задача.

Андрей Викторович Гончаренко. Доктор технических наук. Доцент.

Кафедра сохранения летной годности авиационной техники, Учебно-научный Аэрокосмический институт, Национальный авиационный университет, Киев, Украина.

Образование: Одесский институт инженеров морского флота, Одесса, Украина (1984).

Направление научной деятельности: эксплуатация и управление в активных системах, безопасность полетов, вариационные принципы.

Количество публикаций: более ста.

E-mail: andygoncharenco@yahoo.com 